\title{
Correction to: Effects of robot-assisted gait training in patients with Parkinson's disease: study protocol for a randomized controlled trial
}

Min-Gu Kang ${ }^{1}$, Seo Jung Yun ${ }^{1}$, Hyun lee Shin ${ }^{1}$, Eunkyung Kim¹', Hyun Haeng Lee ${ }^{2}$, Byung-Mo Oh ${ }^{1}$ and Han Gil Seo ${ }^{1 *}$

\section{Correction to: Trials (2019) 20:15}

https://doi.org/10.1186/s13063-018-3123-4

Following publication of the original article [1], the authors identified an error in Tables 1 and 2. The unit of velocity should read ' $\mathrm{km} / \mathrm{h}$ ' instead of ' $\mathrm{m} / \mathrm{s}$ '.

\section{Author details}

'Department of Rehabilitation Medicine, Seoul National University Hospital,

101, Daehak-ro, Jongno-gu, Seoul, South Korea. ${ }^{2}$ Department of

Rehabilitation Medicine, Konkuk University Medical Center, Seoul, South

Korea.

Published online: 27 May 2020

\section{Reference}

1. Kang, et al. Effects of robot-assisted gait training in patients with Parkinson's

disease: study protocol for a randomized controlled trial. Trial. 2019;20:15.

https://doi.org/10.1186/s13063-018-3123-4.

The original article can be found online at https://doi.org/10.1186/s13063018-3123-4.

*Correspondence: hgseo80@gmail.com; hangilseo@snu.ac.kr

'Department of Rehabilitation Medicine, Seoul National University Hospital,

101, Daehak-ro, Jongno-gu, Seoul, South Korea

Full list of author information is available at the end of the article

(c) The Author(s). 2020 Open Access This article is licensed under a Creative Commons Attribution 4.0 International License, which permits use, sharing, adaptation, distribution and reproduction in any medium or format, as long as you give appropriate credit to the original author(s) and the source, provide a link to the Creative Commons licence, and indicate if changes were made. The images or other third party material in this article are included in the article's Creative Commons licence, unless indicated otherwise in a credit line to the material. If material is not included in the article's Creative Commons licence and your intended use is not permitted by statutory regulation or exceeds the permitted use, you will need to obtain permission directly from the copyright holder. To view a copy of this licence, visit http://creativecommons.org/licenses/by/4.0/ The Creative Commons Public Domain Dedication waiver (http://creativecommons.org/publicdomain/zero/1.0/) applies to the data made available in this article, unless otherwise stated in a credit line to the data. 
Table 1. Walkbot-S $\mathrm{S}^{\mathrm{TM}}$ reference and maximal velocities depending on height

\begin{tabular}{llllllll}
\hline & Height & & & & & \\
\cline { 2 - 7 } & $140 \mathrm{~cm}$ & $150 \mathrm{~cm}$ & $160 \mathrm{~cm}$ & $170 \mathrm{~cm}$ & $180 \mathrm{~cm}$ & $190 \mathrm{~cm}$ & $200 \mathrm{~cm}$ \\
\hline Reference velocity $(\mathrm{km} / \mathrm{h})$ & 1.0 & 1.1 & 1.2 & 1.3 & 1.4 & 1.5 & 1.6 \\
Maximal velocity $(\mathrm{km} / \mathrm{h})$ & 1.8 & 2.0 & 2.2 & 2.4 & 2.6 & 2.8 & 3.0 \\
\hline
\end{tabular}

Table 2. Example of a training velocity protocol for a 160-cmtall participant

\begin{tabular}{llllllll}
\hline \multicolumn{7}{l}{ No. of minutes } \\
\cline { 2 - 8 } & $0-5$ & $5-10$ & $10-15$ & $15-20$ & $20-25$ & $25-30$ & 30 \\
\hline Training session no. & Velocity, km/h & & & & \\
1 & 1.2 & 1.2 & 1.4 & 1.4 & 1.7 & 1.7 & 1.7 \\
2 & 1.2 & 1.2 & 1.4 & 1.4 & 1.7 & 1.7 & 1.7 \\
3 & 1.4 & 1.4 & 1.8 & 1.8 & 2.2 & 2.2 & 2.2 \\
4 & 1.4 & 1.4 & 1.8 & 1.8 & 2.2 & 2.2 & 2.2 \\
5 & 1.7 & 1.7 & 2 & 2 & 2.2 & 2.2 & 2.2 \\
6 & 1.7 & 1.7 & 2 & 2 & 2.2 & 2.2 & 2.2 \\
7 & 1.9 & 1.9 & 2.2 & 2.2 & 2.2 & 2.2 & 2.2 \\
8 & 1.9 & 1.9 & 2.2 & 2.2 & 2.2 & 2.2 & 2.2 \\
9 & 1.9 & 1.9 & 2.2 & 2.2 & 2.2 & 2.2 & 2.2 \\
10 & 1.9 & 1.9 & 2.2 & 2.2 & 2.2 & 2.2 & 2.2 \\
11 & 1.9 & 1.9 & 2.2 & 2.2 & 2.2 & 2.2 & 2.2 \\
12 & 1.9 & 1.9 & 2.2 & 2.2 & 2.2 & 2.2 & 2.2 \\
\hline
\end{tabular}

